УДК 342.95

DOI: https://doi.org/10.54929/pmtl-issue1-2021-02

\title{
АДМІНІСТРАТИВНІ КОРУПЦІЙНІ ПРАВОПОРУШЕННЯ: ПОНЯТТЯ, СУТНІСТЬ ТА ОСОБЛИВОСТІ
}

\section{ADMINISTRATIVE CORRUPTION OFFENSES: CONCEPTS, ESSENCE AND FEATURES}

\author{
Кувакін С.В. \\ кандидат юридичних наук, доцент \\ доцент кафедри адміністративного та митного права \\ Університет митної справи та фрінансів
}

Kuvakin S.V.

candidate of Law, Associate Professor Associate Professor administrative and customs law University of Customs and Finance

Стаття присвячена розгляду поняття адміністративні правопорушення, що пов'язані з корупцією як різновиду адміністративного правопорушення. Встановлено, що зазначений вид правопорушень через систематичні посягання на повсякденний порядок діяльності органів публічного управління становить суттєву загрозу різноплановим суспільним відносинам, який формується, зокрема, через адміністративно-правові приписи, заборони та обмеження і через який здебільшого забезпечується стабільне існування держави. Підтверджено, що адміністративним правопорушенням притаманні ряд ознак, які характерні для адміністративних правопорушень, які зводяться до наступних: протиправність, винність, адміністративна караність, діяння, суспільна шкідливість (небезпечність). Доведено, що адміністративним правопорушенням, що пов'язані з корупцією, притаманні всі ознаки, що характеризують будь-яке адміністративне правопорушення, проте мають певні особливості. Ключові слова: адміністративна відповідальність, адміністративне правопорушення, винність, дія, корупція, правопорушення, що пов'язані з корупцією, протиправність.

Статья посвящена рассмотрению понятия административные правонарушения, связанные с коррупцией как разновидности административного правонарушения. Установлено, что указанный вид правонарушений из-за систематических посягательств на повседневный порядок деятельности органов публичного управления представляет существенную угрозу разноплановым общественным отношениям, который формируется, в частности, через административно-правовые предписания, запреты и ограничения и через который в основном обеспечивается стабильное существование государства. Подтверждено, что административным правонарушениям присущ ряд признаков, характерных для административных правонарушений, которые сводятся к следующим признакам: противоправность, виновность, административная наказуемость, деяние, общественная вредность (опасность). Доказано, что административным правонарушениям, связанным с коррупцией, присущи все признаки, характеризующие любое административное правонарушение, однако имеюют определенные особенности. Ключевые слова: административная ответственность, административное правонарушение, виновность, действие, коррупция, правонарушения, связанные с коррупцией, противоправность.

The article deals with the concept of administrative offenses related to corruption as a type of administrative offense. It is established that this type of offense due to systematic encroachments on the daily routine of public administration poses a significant threat to various social relations, which is formed, in particular, through administrative and legal regulations, prohibitions and restrictions and which largely ensures the stable existence of the state. It is confirmed that administrative offenses are characterized by a number of features that are characteristic of administrative offenses, which are as follows: illegality, guilt, administrative punishment, actions, social harm (danger). It has been proven that administrative offenses related to corruption have all the features that characterize any administrative offense, but have certain features. It is stated that administrative offenses related to corruption are a type of administrative offense, ie illegal, guilty actions that contain signs of corruption and for which the law provides for administrative liability. Administrative offenses related to corruption harm the interests of individuals and legal entities, the state, and they create dangerous tendencies that destabilize normal social relations, violate the established order in the state. This type of administrative offense has all the features that characterize any administrative offense, but have certain features. These administrative offenses are a type of administrative offense, ie the result of committing illegal, culpable acts that contain signs of corruption, encroach on the established order of management and for which the law provides for administrative liability. In modern Ukraine, corruption is one of the main problems that hinders the full socio-economic development of the state, undermines trust in public institutions, does not find a 
positive assessment and the necessary support in society at various levels of government and local government. Key words: administrative responsibility, administrative offense, guilt, action, corruption, corruption-related offenses, illegality.

Постановка проблеми у загальному вигляді та її зв'язок із важливими науковими та практичними завданнями. В сучасній Україні корупція $€$ однією із основних проблем, що заважає повноцінному соціально-економічному розвитку держави, підриває довіру до інститутів публічної влади, не знаходять позитивної оцінки та необхідної підтримки у суспільстві на різних рівнях органів державної влади та місцевого самоврядування.

Зазначений вид правопорушень через систематичні посягання на повсякденний порядок діяльності органів публічного управління становить суттєву загрозу різноплановим суспільним відносинам, який формується, зокрема, через адміністративно-правові приписи, заборони та обмеження і через який здебільшого забезпечується стабільне існування держави. Незважаючи на наявність значної кількості наукових праць, які певною мірою висвітлюють проблеми протидії корупційним правопорушенням, нами виявлено потребу у дослідженні питань протидії їм заходами адміністративної відповідальності, що становлять собою вагомий чинник у вирішенні проблеми щодо боротьби з цим негативним явищем. На сьогодні в Україні проблеми фрормування та реалізації антикорупційної політики є одним з найактуальніших, оскільки масштаби поширення корупції становлять реальну загрозу демократичному розвитку суспільства.

Аналіз останніх досліджень і публікацій, в яких започатковано розв'язання даної проблеми і на які спирається автор. Проблема адміністративних правопорушень, пов'язаних із корупцією, не нова в науці адміністративного права. ІІї дослідженню присвятила свої праці низка вітчизняних вчених, зокрема, В.Б. Авер'янов, Н.О. Армаш, О.М. Бандурка, Ю.П. Битяк, В. М. Гаращук, Д.Г. Заброда, В.А. Завгородній, О.Г. Кальман, О.В. Клок, М.І. Мельник, В.Я. Настюк, С.В. Пєтков, А.О. Селіванов, В.М. Соловйов, В.Я. Тацій, О.В. Терещук, І.С. Чаукін та інші вчені-адміністративісти.

Протидія та запобігання корупційним правопорушенням $€$ предметом пильної уваги новостворених державних інститутів держави, в той же час, не залишають поза увагою ці негативні прояви і громадські організації, засоби масової інформації, а також пересічні громадяни. В цьому напрямку, держава зробила чимало кроків, проте реальний стан речей свідчить про недостатні зусилля з боку державних інституцій у боротьби з корупційними правопорушеннями.

Виділення невирішених раніше частин загальної проблеми, котрим присвячується означена стаття. Одними з перших кроків держави було не оновлення антикорупційного законодавства, а прийняття нового, що стало важливим інструментом у протидії корупції. Так, прийняття низки законодавчих актів, починаючи 3 2014 року, спрямованих на боротьбу із корупцією, зумовило й появу в Кодексі про адміністративні правопорушення нової глави 13-А «Адміністративні правопорушення, пов'язані з корупцією», що нараховує на сьогодні 9 статей, які встановлюють адміністративну відповідальність за скоєння корупційних діянь. Проте, різноманітність поглядів на поняття «корупції» обумовлює й багатоаспектність дослідження з точки зору адміністративного законодавства.

Формулювання цілей статті (постановка завдання). Висвітлення проблем визначення адміністративного корупційного правопорушення як різновиду адміністративного правопорушення.

Виклад основного матеріалу дослідження. Досліджуючи питання адміністративних правопорушень, що пов'язані з корупцією слід відштовхуватись від законодавчого поняття адміністративного правопорушення (проступку), що міститься у ч.1 ст.9 КУпАП та крокуючи від загального до конкретного спробуємо визначити особливості правопорушень, пов'язаних з корупцією.

Враховуючи законодавче визначення адміністративного правопорушення традиційно до його ознак належать наступні:

- це діяння, тобто дія чи бездіяльність, а не думки, бажання чи інші подібні прояви психічної діяльності людей. Дія - це активне невиконання обов'язків, законних вимог, а також порушення заборони. Бездіяльність - це пасивне невиконання обов'язків.

- протиправність, що передбачає посягання на загальнообов'язкові правила, встановлені тим чи іншим нормативним актом, які можуть належати не тільки до адміністративного права, але й до інших галузей права. Крім адміністративного, можуть бути норми конституційного, фрінансового, цивільного, трудового та інших галузей права.

- винність визначає, що діяння скоєне умисно або з необережності. Наявність вини - обов'язкова ознака адміністративного правопорушення, відсутність вини виключає визнання дії адміністративним правопорушенням, у тому числі за його фрормальної протиправності.

Проте, перелік цих ознак не $є$ вичерпним, деякі наковці виокремлюють й інші ознаки, що характеризують адміністративне правопорушення. Однак, в розрізі досліджуємого питання та беручи за основу зазначені положення спробуємо визначити особливості адміністративних правопорушень, що пов'язані з корупцією.

Наразі серед науковців, які займаються вивчен- 
ням корупції, не існує однозначної точки зору щодо термінологічного визначення адміністративне корупційне правопорушення та адміністративне правопорушення, пов'язане із корупцією.

Проаналізувавши напрацювання дослідників в антикорупційній галузі, наведемо власне розуміння правової конструкції «адміністративне правопорушення, пов'язане з корупцією». Наголосимо, що її визначення можна навести в широкому й вузькому значенні, оскільки багатоохопленість адміністративного правопорушення, пов'язаного 3 корупцією унеможливлює формування одностайного бачення цього явища. У той же час лише його безпосереднє широке й загальне уявлення і спроби тлумачення, так би мовити, «взагалі по загалям» можуть призвести до констатації науковцями факту наявності адміністративного корупційного правопорушення, що аж ніяк не вирішує проблеми його існування. Пропонуємо розмежовувати це явище в широкому й вузькому розумінні: у широкому - як безпосередньо винна, протиправна поведінка суб'єкта, яка посягає на встановлений порядок управління й за яку адміністративним законодавством передбачено відповідальність; у вузькому - як діяння особи з деформаційним станом правосвідомості, діяльність якої пов'язана зі сферою державного управління, шляхом реалізації нею дій або, навпаки, бездіяльності, що пов'язано з використанням особою свого службового становища під час проходження нею державної служби. Мета таких діянь - корисливі мотиви. Ця пропозиція щодо трактування категорії поняття «корупційне правопорушення» була наведена нами в ракурсі проблематики визначення цього явища в Україні [1, с. 112-113].

В даній статті не вдаючись до термінологічного різноманіття цих двох дефініцій нами наголошується на тому, що вони мають єдине підґрунтя - це, по-перше, є адміністративними правопорушеннями, та, по-друге за їх скоєння передбачена адміністративна відповідальність. На підтвердження цієї позиції звернемося до тих ознак, які характеризують його як адміністративне правопорушення.

Кодекс про адміністративні правопорушення як один із основних актів, в якому містяться переважна більшість адміністративних деліктів надає уніфріковане визначення поняттю «адміністративне правопорушення», яке й поширюється й на адміністративні корупційні правопорушення. Відповідно до ст. 9 Кодексу України про адміністративні правопорушення під адміністративним правопорушенням (проступком) визнається протиправна, винна (умисна або необережна) дія чи бездіяльність, яка посягає на громадський порядок, власність, права і свободи громадян, на встановлений порядок управління і за яку законом передбачено адміністративну відповідальність [2].
У цьому визначенні названо три характерні ознаки правопорушення (проступку): протиправність, винність та адміністративна караність. У теорії адміністративного права крім цих трьох ознак визнається ще й суспільна шкідливість (суспільна небезпечність, антигромадська спрямованість).

Проте, на думку авторів навчального посібника «Адміністративне право» визначення адміністративного правопорушення (проступку) містить обов'язкові ознаки протиправного діяння, яке може бути кваліфіковане як адміністративний проступок:

- протиправність (те, що суперечить праву. За загальним правилом, для приватних осіб дозволено те, що не заборонено законом, а тому, коли говориться про протиправність діяння, йдеться про порушення певної норми права);

- наявність вини (суб'єктивний чинник правопорушення, що вказує на внутрішнє сприйняття правопорушником власного положення про притягнення до адміністративної відповідальності юридичних осіб);

- форма дії (активна поведінка) чи бездіяльності (пасивна поведінка, відсутність дії). Загальною назвою може бути «діяння»; посягання на громадський порядок, власність, права і свободи громадян, на встановлений порядок управління.

Перелік означених загальних об'єктів, на які можуть посягати протиправні діяння, не є вичерпним, він переважно встановлює напрямки, в яких правовідносини охороняються адміністративно-деліктним законодавством; наявність у законі прямої вказівки на адміністративну відповідальність за конкретне діяння [3, с. 285-286].

Виходячи із наведеного, можна виокремити ряд ознак, які характерні для адміністративних правопорушень (проступків), які, як правило, в юридичній літературі зводять до наступних: протиправність, винність, адміністративна караність, діяння, суспільна шкідливість (небезпечність), в результаті здійснення якої мають місце порушення громадського порядку, відносин власності, прав і свобод громадян, а також наявного порядку управління.

Підтримуючи останню позицію, слід більш детальніше зупинитися на цих ознаках.

Протиправність. Існують два основних підходи до визначення змісту протиправності адміністративного правопорушення:

протиправність означає, що діяння полягає в порушенні приписів правових норм, за що встановлена юридична відповідальність;

- протиправність полягає в забороні вчинення певних діянь шляхом установлення за них юридичної відповідальності [4, с.105].

Винність, тобто це свідомий вольовий акт протиправної поведінки. Вина полягає в психічному ставленні суб'єкта до протиправного діяння і його негативним наслідкам та може бути умисною або 
з необережністю. Якщо в діянні відсутня вина, то воно не є правопорушенням. Суб'єктивна сторона знаходить свій прояв виключно у формі прямого умислу. Іншими словами, особа, яка їх учинила, усвідомлювала протиправний характер своїх дій чи бездіяльності, передбачала шкідливі наслідки і знала про їх настання. Особливу увагу звернемо на той фракт, що жодне адміністративне корупційне правопорушення не вчиняється з необережності

Адміністративна караність проступку як ознака полягає в тому, що за його вчинення, особа повинна нести лише адміністративну відповідальність. Наслідком вчинення проступку повинна бути негативна реакція з боку державних органів у вигляді застосування до винної особи стягнення, передбаченого Кодексом України про адміністративні правопорушення.

Об'єктом посягання будь-яких адміністративних правопорушень визнаються суспільні відносини, на які посягає правопорушник. Якщо проаналізувати надане законодавцем визначення адміністративного правопорушення (проступку), що міститься у ст.9 КУпАП, то можна зробити висновок, що об'єктом посягання всіх адміністративних правопорушень може виступати громадський порядок, власність, права і свободи громадян, встановлений порядок управління.

Однак, аналіз усіх юридичних складів адміністративних деліктів, що пов'язані з корупцією, а їх всього дев'ять, засвідчує, що законодавець дещо звузив об'єкт посягання адміністративних правопорушень, оскільки зазначені правопорушення спрямовані на порушення вимог Закону України «Про запобігання корупції», де наводиться таке формулювання: «корупція - використання особою, зазначеною у частині першій статті 3 цього Закону, наданих їй службових повноважень чи пов'язаних з ними можливостей з метою одержання неправомірної вигоди або прийняття такої вигоди чи прийняття обіцянки/пропозиції такої вигоди для себе чи інших осіб або відповідно обіцянка/пропозиція чи надання неправомірної вигоди особі, зазначеній у частині першій статті 3 цього Закону, або на ії вимогу іншим фрізичним чи юридичним особам з метою схилити цю особу до протиправного використання наданих їй службових повноважень чи пов'язаних з ними можливостей» [5].

Крім того, зауважимо, що в середовищі українських учених-правознавців та практиків не вироблено чіткого визначення поняття корупції. Основні підходи щодо розуміння корупції можна звести до таких: корупцію розуміють як підкуп-продажність державних службовців; корупцію розглядають як зловживання владою або посадовим становищем, здійснене з певних особистих інтересів або в інтересах інших осіб; корупцію розуміють як використання посадових повноважень, статусу посади, а також ії авторитету для задоволення особистого інтересу або інтересів третіх осіб [6, c. 7].

Суспільна шкідливість (небезпечність) дії чи бездіяльності означає, що вона заподіює або створює загрозу заподіянням шкоди або створенням небезпеки об'єктам адміністративно-правової охорони, які передбачені у ст. 9 КУпАП. Проаналізувавши всі юридичні склади адміністративних правопорушень, що містяться у главі 13-А КУпАП, можемо дійти висновку, що кожен з них передбачає наявність свідомої вольової активної поведінки правопорушника, тобто зазначені діяння вчиняються у формі дії.

В українській адміністративно-правовій концепції виникає три варіанти вирішення проблеми співвідношення шкідливості та суспільної небезпеки як ознак адміністративного проступку. Перший погляд (Л.В. Коваль) полягає в тому, що поняття «суспільна небезпека» $€$ загальним. Характеристики загального - це ступінь і кількість. Ступінь визначається питомою вагою шкоди. Кількість визначається повторністю та рецидивом. Другий погляд (І.П. Голосніченко) полягає в тому, що загальним $€$ поняття «шкідливість». Зростання або зниження питомої ваги шкідливості утворює відповідну ступень суспільної небезпеки. Третій погляд (Є.В. Додін) полягає в тому, що поняття «суспільна небезпека» $є$ загальним. Характеристики загального - це характер, що має якісний зміст, і ступінь, що має кількісний зміст. Зростання або зниження питомої ваги кількісних показників, відповідно до законів діалектики, впливає на якісний зміст, тобто на характер. Отже, незважаючи на тривалість дискусії щодо проблеми суспільної небезпеки адміністративних правопорушень, можна констатувати спільність поглядів її учасників у визнанні негативного характеру усіх правопорушень. Негативна ж оцінка не може полягати в чомусь іншому, крім шкоди та суспільної небезпеки [7].

Першоосновою будь-якого проступку є його ознаки та юридичний склад, які й вирізняють адміністративне правопорушення від інших діянь, що не носять характер протиправних. Такі ознаки безпосередньо визначені у дефрініції проступку, що закріплено у відповідних положеннях КУпАП, у тому числі:

а) вчинення фрізичною особою протиправної дії чи бездіяльності - невиконання чи порушення приписів або заборон, встановлених нормами адміністративного законодавства;

б) вчинення умисної або необережної дії чи бездіяльності, яка посягає на громадський порядок, власність, права і свободи громадян, на встановлений порядок публічного управління, зокрема проступок визнається вчиненим умисно, коли правопорушник усвідомлював протиправний характер свого діяння, передбачав шкідливі наслідки і бажав їх або свідомо допускав настання цих 
наслідків, тоді як необережність в таких діяннях характеризується передбаченням можливості настання шкідливих наслідків, але відповідна особа легковажно розраховувала на їх відвернення або не передбачала можливості настання таких наслідків, хоч повинна була і могла їх передбачити;

в) передбачення положеннями адміністративного законодавства застосування до винної особи чи групи осіб адміністративної відповідальності за протиправну дію чи бездіяльність - будь-яка людина, яка вчинила проступок має понести тягар негативної реакції публічної влади, що реалізується у накладенні певних адміністративних стягнень.

Використовуючи онтологію та гносеологію права як методи дослідження адміністративно-деліктного середовища, у своєму дисертаційному дослідженні В.К. Колпаков розмежовує онтологічні і гносеологічних ознаки делікту. На переконання науковця наведений нами перелік відноситься до сфрери адміністративно-правової онтології, зважаючи на те, що вітчизняний законодавець ставить за мету з допомогою юридичної техніки шляхом переліку найбільш характерних ознак як можна точніше описати факт, реальне явище буття 3 уникненням суб'єктивних фракторів. Гносеологічні ознаки виводяться шляхом дослідження відповідних ознак з допомогою науково обґрунтованих методів і опису отриманих результатів [8, с. 156].

У наступних працях цей автор розвинув теорію щодо ознак і складу проступку, однак вибрав інший підхід у питаннях термінології без врахування положень онтології та гносеології права. Так, ознаки наведені в ст. 9 КУпАП є апостеріорними або емпіричними, тоді як ознаки, які містить поняття «склад адміністративного проступку», $€$ апріорними або теоретичними. Співвідношення наведеного полягає у тому, що знання, які попередньо були одержані досвідним шляхом, у подальшому передують досвідові, організовують і спрямовують його. Вони є інструментом, який слугує для набуття і формування нових знань теоретичного рівня. Ці ознаки фріксуються у законі як результат узагальнення історичного досвіду щодо детермінації небажаних для суспільства діянь. Їхнє нормативне закріплення є орієнтиром для попередньої кваліфрікації адміністративного правопорушення [9, с. 24-25].

Адміністративні правопорушення, що пов'язані з корупцією, безумовно, завдають шкоди інтересам фрізичних та юридичних осіб, державі, при цьому, вони створюють небезпечні тенденції, які дестабілізують нормальні суспільні відносини, порушують усталений порядок в державі. Зазначеному виду адміністративного правопорушення притаманні всі ознаки, що характеризують будьяке адміністративне правопорушення, проте мають певні особливості.

Виходячи із вищенаведеного стверджуємо, що адміністративні правопорушення, пов'язані з корупцією - це різновид адміністративного правопорушення, тобто протиправні, винні дії, що містять ознаки корупції та за які законом передбачено адміністративну відповідальність.

Висновки $з$ цього дослідження. Адміністративні правопорушення, що пов'язані з корупцією, завдають шкоди інтересам фрізичних та юридичних осіб, державі, при цьому, вони створюють небезпечні тенденції, які дестабілізують нормальні суспільні відносини, порушують усталений порядок в державі. Зазначеному виду адміністративного правопорушення притаманні всі ознаки, що характеризують будь-яке адміністративне правопорушення, проте мають певні особливості. Зазначені адміністративні правопорушення $є$ різновидом адміністративного правопорушення, тобто результатом скоєння протиправних, винних дій, що містять ознаки корупції, посягають на встановлений порядок управління та, за які законом передбачено адміністративну відповідальність.

У зв'язку із вищенаведеним, слід констатувати, що ті об'єкти посягання, що наведені у ч.1 ст. 9 КУпАП не містять ті суспільні відносини, що виступають об'єктом посягання адміністративних правопорушень, що пов'язані із корупцією. Однак, на наш погляд, перерахування всіх об'єктів посягання у законодавчому визначенні адміністративних правопорушень може й не дати бажаного результату, оскільки розвиток суспільних відносин може призвести й до виникнення нових об'єктів адміністративно-правової охорони.

\section{БІБЛІОГРАФІЧНИЙ СПИСОК:}

1. Клок О.В. Особливості проявів корупційних правопорушень в інформаційній сфері. Юрист України. 2013. № 1. C. 111-115.

2. Кодекс України про адміністративні правопорушення. Відомості Верховної Ради Української РСР (ВВР). 1984, додаток до № 51, ст.1122.

3. Алфььоров С.М., Ващенко С.В., Долгополова М.М., Купін А.П. Адміністративне право. Загальна частина. Навч. посіб. К.: Центр учбової літератури, 2011. 216 с.

4. Лук'янець Д.М. Адміністративно-деліктні відносини в Україні: теорія та практика регулювання: Монографрія. Суми, 2006. 367.

5. Про запобігання корупції: Закон України від 14.10.2014 р. Відомості Верховної Ради У країни. 2014. № 49. Ст. 2056.

6. Різак І. М., Бисага Ю.М., Палінчак М. М. та ін. Корупція як негативне соціальне явище: шляхи її подолання 
в Україні та міжнародний досвід. Ужгород: Ліра, 2004. С. 7.

7. Колпаков В.К. Фактичні ознаки та юридичний склад адміністративного проступку: поняття та розмежування.

URL: http://www.law.journalsofznu.zp.ua/archive/visnik-3-2016/26.pdf.

8. Колпаков В.К. Деліктний феномен в адміністративному праві України: дис. ... докт. юрид. наук: 12.00.07. Національна академія внутрішніх справ України. Київ, 2005. 455 с.

9. Колпаков В.К. Адміністративна відповідальність (адміністративно-деліктне право): навч. посібник. К.: Юрінком Інтер, 2008.256 с.

\section{REFERENCES:}

1. Klok, O.V (2013). Peculiarities of manifestations of corruption offenses in the information sphere. Lawyer of Ukraine. 1. 111-115. (in Ukrainian).

2. Code of Ukraine on Administrative Offenses. Information of the Verkhovna Rada of the Ukrainian SSR (VVR). 1984, supplement to № 51, p.1122. (in Ukrainian).

3. Alferov, S.M., Vashchenko, S.V., Dolgopolova M.M., Kupin A.P. (2011). Administrative Law. The general part. Teaching way. Kyiv. (in Ukrainian).

4. Lukyanets, D.M. (2006). Administrative-tort relations in Ukraine: theory and practice of regulation: Monograph. Sumy. (in Ukrainian).

5. On Prevention of Corruption: Law of Ukraine of October 14, 2014. Information of the Verkhovna Rada of Ukraine. 2014. № 49. 2056. (in Ukrainian).

6. Rizak, I.M., Bisaga, Y.M., Palinchak, M.M. etc (2004). Corruption as a negative social phenomenon: ways to overcome it in Ukraine and international experience. Uzhhorod. (in Ukrainian).

7. Kolpakov, V.K.(2016). Factual features and legal structure of administrative misconduct: concepts and distinctions URL: http://www.law.journalsofznu.zp.ua/archive/visnik-3-2016/26.pdf. (in Ukrainian).

8. Kolpakov, V.K. (2005). Tort phenomenon in the administrative law of Ukraine: dis. ... Dr. Low Science: 12.00.07. National Academy of Internal Affairs of Ukraine. Kyiv. (in Ukrainian).

9. Kolpakov, V.K. (2008). Administrative liability (administrative tort law): textbook. manual. Kyiv. (in Ukrainian). 